\title{
The mediating effect of innovation on the relationship between supplier collaboration and environmental performance
}

\author{
Gun Jea Yu ${ }^{\mathrm{a}}$ and Joonkyum Lee $\mathrm{b}^{\mathrm{b}^{*}}$
}

${ }^{a}$ College of Business Administration, Hongik University, 94 Wausan-ro, Mapo-gu, Seoul 04066, Korea, South Korea ${ }^{b}$ Sogang Business School, Sogang University, 35 Baekbeom-ro, Mapo-gu, Seoul, 04107, Korea, South Korea

\begin{tabular}{l}
\hline C H R O N I C L E \\
\hline Article history: \\
Received April 21, 2020 \\
Received in revised format June \\
8,2020 \\
Accepted June 152020 \\
Available online \\
June 15 2020 \\
\hline Keywords: \\
Environmental performance \\
Collaboration \\
Supplier \\
Innovation \\
Mediation \\
\hline
\end{tabular}
A B S T R A C T

\begin{abstract}
Environmental sustainability can require extensive investment from suppliers as well as firms. Previous studies on this topic focused on the direct relationship between supplier collaboration and environmental performance, yet these studies did not investigate the mechanism behind the relationship. Our study examines the mediating role of innovation on the relationship between supplier collaboration and environmental performance. We tested this model using a sample of 597 Korean firms and found that innovation positively mediated the collaboration effect with suppliers through measurements of strategic, operational, and product development collaboration. These results help us identify the process through which supplier collaboration leads to better environmental performance.
\end{abstract}

\section{Introduction}

C 2020 by the authors; license Growing Science, Canada.

The intensifying interest in environmental performance from diverse stakeholders such as customers, governments, and suppliers has increased the importance of environmental management to most firms (Henriques \& Sadorsky, 1999). To address this concern, firms have expanded the scope of environmentally-focused activities from internal initiatives to external projects, including environmentally-friendly supply chains (Rao \& Holt, 2005) and reverse logistics (Prahinski \& Kocabasoglu, 2006). Since these activities require firms to interact with external stakeholders like suppliers, customers, and competitors, policymakers must understand how firms collaborate with external stakeholders to encourage more sustainable processes. In this study, we investigate the effect of supplier collaboration on environmental performance and explore the mechanism between the two. Environmental performance innovation tends to be more complex than general innovation and thus needs more interdependency among technologies (Gimenez \& Tachizawa, 2012; De Marchi, 2012); supplier collaboration can play a vital role in better understanding how to best utilize complex and difficult technology. While these previous studies have focused on the direct effect of supplier collaboration on environmental performance, demonstrating that suppliers can provide complementary experience, we extend this argument by revealing how supplier collaboration is positively related with environmental performance.

The rationale for the mediating effect is that firms improve innovation capabilities by collaborating with suppliers and then the increased innovation capabilities lead to high environmental performance. For example, De Marchi (2012) argued that supplier collaboration is beneficial for environmental performance due to absorptive capacity; Vachon and Klassen (2008) echoed the importance of resources and capabilities in explaining the positive relationship between supplier collaboration and environmental performance. Many researchers supported the positive impact of supplier collaboration on environmental performance using the innovation capability concept, yet little research has been attempted to prove the mediating role of

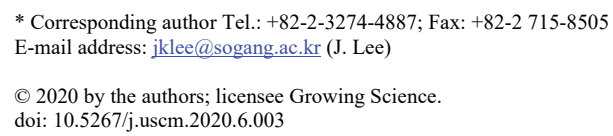


innovation capability and clarify the specific mechanism by which supplier collaboration improves environmental performance.

This research contributes to the current literature by examining the mediating effect of innovation between supplier collaboration and environmental performance. The mediating effect of innovation can provide a better understanding of environmental performance. In addition, we consider three types of supplier collaboration: strategic, operational, and joint product development; these levels are sufficiently uncorrelated to support different theoretical backgrounds. Our intent is to help firms understand these different approaches to collaboration and enable firms to build good collaborative relationships with their suppliers.

The paper is organized as follows. First, we explain the relationship between the three types of supplier collaboration and environmental performance, the effect of innovation on environmental performance, and the mediating effect of innovation. Next, we describe the data, empirical model, and the interpretation of results. To conclude, we address the contributions and limitations of this study.

\section{Literuare review and hypothese development}

Environmental innovation is typically categorized into managerial, process, and product innovations (Chen, 2008; Chiou et al., 2011). Similarly, we classify supplier collaboration into strategic, operational, and product development collaboration. Strategic collaboration refers to leaders sharing business issues and goals with each other to maintain and grow the relationship (Srivastava, 2007). Operational collaboration leads to modified manufacturing processes that decrease negative impacts on the environment (Klassen \& Whybank, 1999), whereas product development collaboration involves designing new products or refining existing products that inherently reduce negative environmental impacts (Klassen \& Whybank, 1999). We have distinguished these three types of collaboration because each is derived from different theoretical backgrounds using different approaches.

\subsection{The relationship between supplier collaboration and environmental performance}

\subsubsection{Strategic collaboration with suppliers}

Strategic collaboration with suppliers refers to leaders sharing business issues, information, and goals to keep the relationship (Srivastava, 2007). Strategic collaboration with suppliers can enhance environmental performance by increasing the depth of understanding between partners and improving trust. Eco-friendly technology tends to be very complex and is constantly evolving, requiring skills and knowledge best provided by smaller, nimbler suppliers (Rothenberg, 1999). In addition, environmental innovations rely on cospecialized complementary assets for successful implementation; these assets and the accompanying tacit knowledge are difficult to transfer across companies (Teece, 1986). Strategic collaboration therefore enables firms to obtain important processes and best practices from suppliers and more smoothly incorporate complex and co-specialized technology. Geffen and Rothenberg (2000) demonstrated that when firms openly share strategies and goals with their supply chain, their suppliers provide more expertise and knowledge, resulting in better environmental performance. In addition, strategic collaboration increases trust, forming long-term partnerships that enable firms to address diverse environmental issues. Therefore, we suggest the following hypothesis.

Hypothesis 1-1: Strategic collaboration with suppliers is positively associated with environmental performance.

\subsubsection{Operational collaboration with suppliers}

Leveraging relationships with suppliers to improve operations also enhances environmental performance. Suppliers can contribute to improvements in product quality, costs, and schedules (Primo \& Amundson, 2002; Song \& Thieme, 2009), which reduces rework, scrap, emissions, and energy consumption. The complementary knowledge provided by suppliers plays an important role in improving current processes and resolving existing operational problems (Bonaccorsi \& Lipparini, 1994) as well as identifying and implementing new operational technologies. Firms are most successful when they continually improve environmental performance and stay ahead of regulations (Green et al., 1998). The implementation of new operational systems also requires supplier knowledge and experience. Thus, we suggest the following hypothesis.

\section{Hypothesis 1-2: Operational collaboration with suppliers is positively associated with environmental performance.}

\subsubsection{Product development collaboration with suppliers}

Collaborating with suppliers during product development also increases environmental performance. Environmental performance literature has so far been focused on environmentally friendly products for cleaning technologies and pollution prevention (Bakker et al., 2002). Similarly, Dangelico and Pujari (2010) argued that firms are paying more attention to the environmental performance of their products because environmental policies emphasize those product characteristics. Regardless, developing environmentally friendly products requires complex skillsets and a strong foundation in materials 
science. To successfully reduce the environmental footprint of their products, firms must access the external complementary knowledge that their suppliers have obtained by working with varied manufacturers (Clark \& Fujimoto, 1991). For example, automakers improved their paint processes by combining new environmentally-friendly paint chemistries suggested by suppliers with the knowledge and skills of their automobile assembly teams (Geffen \& Rothenberg, 2000). Geffen (1998) further proved this point by analyzing paint industry patents and finding that suppliers are the main source of innovative products that reduce environmental impact through new materials and chemical design. We expect that the knowledge and experience that suppliers provide will help firms use new material and components to develop more environmentally friendly products, so we suggest the following hypothesis.

Hypothesis 1-3: Product development collaboration with suppliers is positively associated with environmental performance.

\subsection{The impact of innovation on environmental performance}

We have seen a stream of literature supporting a positive relationship between innovation and environmental performance, where innovation can directly and indirectly influence environmental performance. An example of a direct influence is when innovations reduce labor, material, and energy usage and thereby improve productivity and processes. MondéjarJiménez et al. (2015) empirically showed that a company focusing on enhancing productivity through innovation will improve its environmental performance. In addition, quality management innovations also benefit environmental performance by reducing waste and rework. For example, King and Lenox (2001) showed that quality improvement is complementary to waste and pollution reduction, which implies that innovations can enhance environmental performance by increasing productivity and lowering defects. Jakobsen and Clausen (2016) found that process innovation reduces labor and material costs, demonstrating that manufacturing process innovation also has a positive effect on environmental performance. In conclusion, innovation designed to improve productivity, whether through quality management or process improvement, directly enhances environmental performance. Innovation can also indirectly improve environmental performance since most inventions will facilitate and complement environmental innovation (Rothenberg \& Zyglidopoulos, 2007). As Rogers (1983) demonstrated, many environmental innovations require compatible systems, in which case firms need related product technologies to successfully adopt the new innovations. Innovation capabilities increase the ability to adopt new knowledge and technology, raising the likelihood that firms have the required level of compatibility for a given new technology (Cohen \& Levinthal, 1990). Therefore, highly-innovative firms can adopt new environmental technologies quickly and smoothly to improve environmental performance and meet shifting environmental regulations.

\section{Hypothesis 2: Innovation is positively related to environmental performance.}

\subsection{The mediation effect of innovation on the relationship between supplier collaboration and environmental performance}

Firms can improve innovation through deeper collaboration with their suppliers. Strategic collaboration provides a longterm relationship that leads to deep trust (Chiou et al., 2011), which provides the foundation for long-term support and cooperation with suppliers. This collaboration helps firms meet quality targets, budgets, and schedules (Primo \& Amundson, 2002; Song \& Thieme, 2009) and enables firms to more effectively implement innovations. Suppliers also play an important role in identifying new technologies and material components that could enhance innovation performance. Strong collaboration with suppliers during product development encourages suppliers to share information (Ragatz, Handfield, \& Petersen, 2002; Takeishi, 2001), reducing unnecessary changes and rework (Loch \& Terwiesch, 1998) as well as redundant tasks (Tannenbaum, Beard, \& Salas, 1992).

This type of openness also improves the accuracy with which firms can schedule new product development, which is critical to successfully launching modern products. Collaboration enables interdependent communication between the firm and supplier about technical and organizational realities, allowing both to more readily adjust the timing of new product development (Campion, Medsker, \& Higgs, 1993; Hoegl \& Gemuenden, 2001). Overall, the three types of supplier collaboration help firms reach higher innovation.

Firms can utilize improved innovation by collaborating with suppliers to increase environmental performance. Although most firms are structured to quickly respond to changing stakeholder needs through strong innovation (Cooper \& de Brentani, 1991), environmental performance is unique in requiring technologies that are quite complex, so firms need to incorporate additional requirements from even more stakeholders to improve environmental performance (De Marchi, 2012). This implies that firms reach a high level of environmental performance through strong innovation capabilities, including quick response and absorptive processes, which can handle complex technologies and combine multiple technology domains (Goldenberg, Lehman, \& Mazursky, 1999; Colarelli O’Connor, 1998). Figure 1 illustrates our proposed research model.

\section{Hypothesis 3: Innovation mediates the relationship between supplier collaboration and environmental performance.}




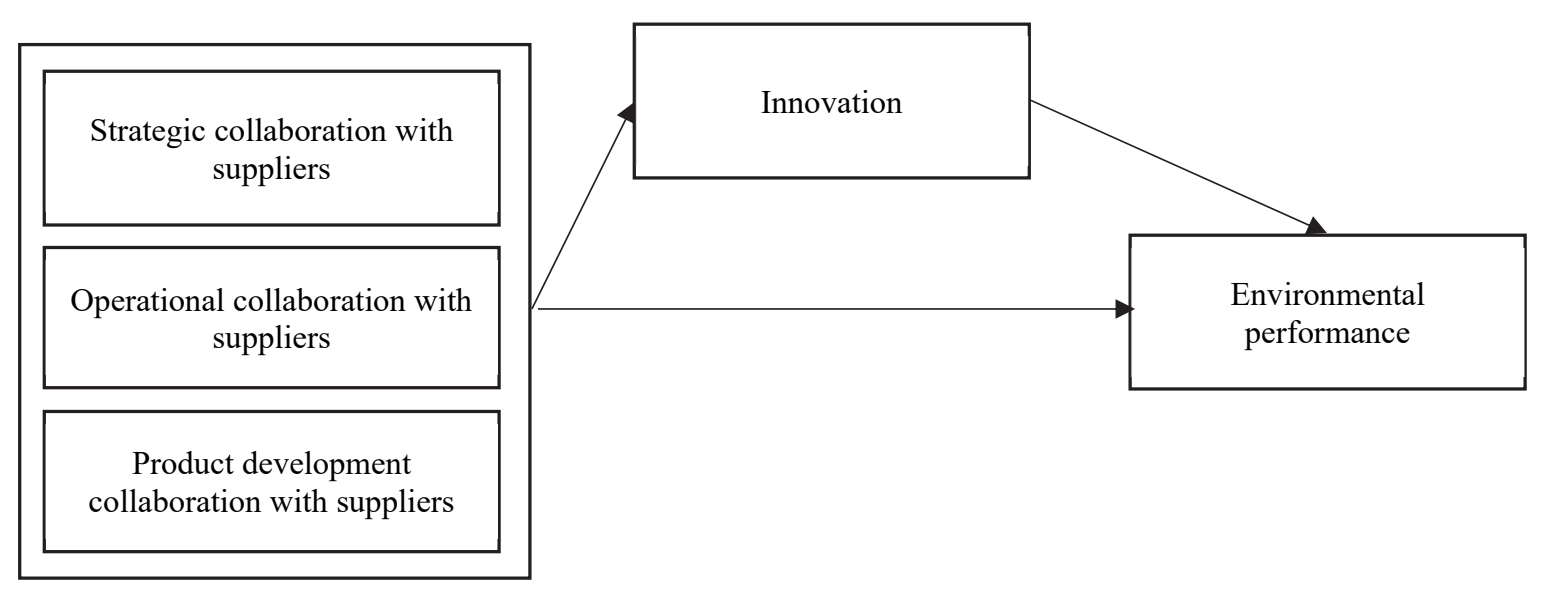

Fig. 1. Research model.

\section{Methodology and measurement}

\subsection{Data Collection}

We used data from the Korean manufacturing panel survey in 2013 for testing hypotheses. The sample contains 601 responses out of the 2,000 firms contacted, of which we used 597 after screening for missing data. Most (80\%) were small and medium-sized firms and belonged to four industries: automobile, machine, shipbuilding, and telecommunication. Our sample set worked well for this study because each of these firms needs to conform to environmental regulations including Waste Electric and Electronic Equipment.

\subsection{Measures}

Environmental performance. We measured the dependent variable, environmental performance, by evaluating the quantitative reduction in four categories (non-renewable resources, emissions to air and water, energy, and inputs), similar to the approach used by Wagner and Schaltegger (2004). Our respondents conveyed the amount to which their firms reduced their environmental footprint using a scale of one (no reduction) to seven (significant reduction).

Innovation. We captured the mediating variable, innovation, using the number of patents during the preceding three years. We used a log scale to transform this variable due to the data distribution's skewness.

Strategic collaboration with suppliers. We measured strategic supplier collaboration, an independent variable, with three questions using a seven-point Likert scale. For example, one question asked "Does your firm share or discuss important business issues with your suppliers?" and another asked "Does your firm share business goals with suppliers?" Cronbach's alpha was .83 in the results, indicating relatively high reliability.

Operational collaboration with suppliers. We measured operational supplier collaboration, an independent variable, with four questions using a seven-point Likert scale. For example, one question asked "Does your firm share information about customers and markets with suppliers?" and another asked "Does your firm share information about inventory?" Cronbach's alpha was .90 for this variable, indicating high reliability.

Product development collaboration with suppliers. We measured product development collaboration with suppliers, the final independent variable, using four items that also used using a 7-point Likert scale of 1 (very low) to 7 (very high). For example, one question asked "Does your firm's product development system link with a supplier's system?" and another asked "Does your firm encourage suppliers to suggest new technology or knowledge?" Cronbach's alpha was .90 for this variable, indicating high reliability.

Control variables. We created three variables at the firm level: we used the total annual R\&D budget to control for the basic capability of innovation, we controlled for maturity through the years an organization has operated, and we used the number of employees to control for firm size. 


\section{Results}

Table 1 contains descriptive statistics and correlations. We found significant correlations among the variables, showing that all three of supplier collaboration approaches that we chose (strategic, operational, and product development) were associated with both innovation and environmental performance. We used variance inflation factors (VIF) to check multicollinearity. The range of VIF was between 1.28 and 1.31 , below the commonly-accepted maximum of 10 , indicating that our results were not affected by multi-collinearity.

Table 1

Mean, standard deviation, and correlation coefficient.

\begin{tabular}{|c|c|c|c|c|c|c|c|c|c|c|c|}
\hline No & Variable & Mean & S. D. & 1 & 2 & 3 & 4 & 5 & 6 & 7 & 8 \\
\hline 1 & Environmental performance & 4.21 & 0.91 & 1 & & & & & & & \\
\hline 2 & Innovation & 4.24 & 1.09 & $0.26^{*}$ & 1 & & & & & & \\
\hline 3 & Strategic collaboration & 4.84 & 0.99 & $0.19 *$ & $0.14 *$ & 1 & & & & & \\
\hline 4 & Operational collaboration & 4.79 & 1.16 & $0.17 *$ & $0.17 *$ & $0.69 *$ & 1 & & & & \\
\hline 5 & Product development collaboration & 4.54 & 1.16 & $0.2^{*}$ & $0.25 *$ & $0.66 *$ & $0.67 *$ & 1 & & & \\
\hline 6 & Firm age & 18.53 & 11.31 & $0.08 *$ & 0.07 & 0.06 & 0.01 & 0.07 & 1 & & \\
\hline 7 & Firm size & 4.65 & 0.88 & 0.05 & 0.07 & $0.13 *$ & $0.15^{*}$ & $0.16^{*}$ & $0.34 *$ & 1 & \\
\hline 8 & R\&D & 1.50 & 0.91 & 0.06 & $0.32 *$ & 0.03 & 0.01 & $0.11 *$ & $0.2^{*}$ & $0.11 *$ & 1 \\
\hline
\end{tabular}

Table 2 shows the ordinary least squares (OLS) regression analyses, where Model 1, the baseline model, includes control variables. We examine the effects of collaboration using Model 2, 3, and 4, which shows that strategic collaboration $(\beta=0.169, \mathrm{p}<0.001)$, operational collaboration $(\beta=0.131, \mathrm{p}<0.001)$, and product development collaboration $(\beta=0.151$, $\mathrm{p}<0.001)$ are each positive and significant, supporting hypothesis $1.1,1.2$, and 1.3. Using Model 5, we show that innovation is associated with environmental performance $(\beta=0.224, \mathrm{p}<0.001)$ positively and significantly, supporting hypothesis 2 .

Table 2

Results of OLS regression analyses

\begin{tabular}{|c|c|c|c|c|c|c|c|c|}
\hline & Model 1 & Model 2 & Model 3 & Model 4 & Model 5 & Model 6 & Model 7 & Model 8 \\
\hline DV & \multicolumn{8}{|c|}{ Environmental performance } \\
\hline Firm age & $\begin{array}{l}0.005 \\
(0.00)\end{array}$ & $\begin{array}{l}0.004 \\
(0.00)\end{array}$ & $\begin{array}{l}0.005 \\
(0.00)\end{array}$ & $\begin{array}{l}0.004 \\
(0.00)\end{array}$ & $\begin{array}{l}0.005 \\
(0.00)\end{array}$ & $\begin{array}{l}0.004 \\
(0.00)\end{array}$ & $\begin{array}{l}0.005 \\
(0.00)\end{array}$ & $\begin{array}{l}0.004 \\
(0.00)\end{array}$ \\
\hline Firm size & $\begin{array}{l}0.026 \\
(0.05)\end{array}$ & $\begin{array}{l}0.019 \\
(0.05)\end{array}$ & $\begin{array}{l}0.014 \\
(0.05)\end{array}$ & $\begin{array}{l}0.013 \\
(0.05)\end{array}$ & $\begin{array}{l}0.012 \\
(0.04)\end{array}$ & $\begin{array}{l}0.006 \\
(0.04)\end{array}$ & $\begin{array}{l}0.004 \\
(0.05)\end{array}$ & $\begin{array}{l}0.004 \\
(0.05)\end{array}$ \\
\hline $\mathrm{R} \& \mathrm{D}$ & $\begin{array}{l}0.024 \\
(0.04)\end{array}$ & $\begin{array}{l}0.016 \\
(0.04)\end{array}$ & $\begin{array}{l}0.020 \\
(0.04)\end{array}$ & $\begin{array}{l}0.002 \\
(0.04)\end{array}$ & $\begin{array}{l}-0.051 \\
(0.04)\end{array}$ & $\begin{array}{c}-0.050 \\
(0.04)\end{array}$ & $\begin{array}{l}-0.047 \\
(0.04)\end{array}$ & $\begin{array}{l}-0.057 \\
(0.04)\end{array}$ \\
\hline $\begin{array}{c}\text { Strategic } \\
\text { collaboration }\end{array}$ & & $\begin{array}{c}0.169^{* * *} \\
(0.04)\end{array}$ & & & & $\begin{array}{c}0.141 * * * \\
(0.04)\end{array}$ & & \\
\hline $\begin{array}{l}\text { Operational } \\
\text { collaboration }\end{array}$ & & & $\begin{array}{c}0.131 * * * \\
(0.03)\end{array}$ & & & & $\begin{array}{c}0.101 * * \\
(0.03)\end{array}$ & \\
\hline $\begin{array}{c}\text { Product } \\
\text { development } \\
\text { collaboration }\end{array}$ & & & & $\begin{array}{c}0.152 * * * \\
(0.03)\end{array}$ & & & & $\begin{array}{c}0.114 * * * \\
(0.03)\end{array}$ \\
\hline Innovation & & & & & $\begin{array}{c}0.224 * * * \\
(0.04)\end{array}$ & $\begin{array}{c}0.208 * * * \\
(0.04)\end{array}$ & $\begin{array}{c}0.207 * * * \\
(0.04)\end{array}$ & $\begin{array}{c}0.198 * * * \\
(0.04)\end{array}$ \\
\hline _cons & $\begin{array}{c}3.993 * * * \\
(0.23)\end{array}$ & $\begin{array}{c}3.213 * * * \\
(0.28)\end{array}$ & $\begin{array}{c}3.391 * * * \\
(0.27)\end{array}$ & $\begin{array}{c}3.383 * * * \\
(0.26)\end{array}$ & $\begin{array}{c}3.217 * * * \\
(0.25)\end{array}$ & $\begin{array}{c}2.618 * * * \\
(0.29)\end{array}$ & $\begin{array}{c}2.804 * * * \\
(0.28)\end{array}$ & $\begin{array}{c}2.844 * * * \\
(0.27)\end{array}$ \\
\hline $\begin{array}{l}\text { adj. } \mathrm{R}^{2} \\
\mathrm{~N}\end{array}$ & $\begin{array}{c}0.014 \\
572\end{array}$ & $\begin{array}{c}0.044 \\
572\end{array}$ & $\begin{array}{c}0.037 \\
572\end{array}$ & $\begin{array}{c}0.046 \\
572\end{array}$ & $\begin{array}{c}0.076 \\
572\end{array}$ & $\begin{array}{c}0.096 \\
572\end{array}$ & $\begin{array}{c}0.089 \\
572\end{array}$ & $\begin{array}{c}0.092 \\
572\end{array}$ \\
\hline
\end{tabular}
in this table.

We conducted two tests to examine the mediating effect of innovation on the relationship between supplier collaboration and environmental performance. We begin by testing the mediating effect using three-step analysis of Baron and Kenny (1986). In the first step, we find that the three types of supplier collaboration are positively and significantly related with environmental performance, supporting hypotheses 1.1, 1.2, and 1.3. In the second step, we find that the mediator, innovation, is also positively and significantly related with environmental performance. In the third step, we test the effect of the mediator on the dependent variable while controlling for the three types of supplier collaboration. We find significant influence of innovation on environmental performance with a significant effect from the three types of supplier collaboration: innovation $\beta=0.208, p<0.001$ with strategic collaboration $\beta=0.141, p<0.001$; innovation $\beta=0.207, p<0.001$ with operation collaboration $\beta=0.101, \mathrm{p}<0.001$; innovation $\beta=0.198, \mathrm{p}<0.001$ with product development collaboration $\beta=0.114, p<0.001$. The results imply a partial mediation effect of innovation and support hypothesis 3 .

Additionally, we used a Sobel test to examine the mediation effect (Sobel, 1986). We use the product of coefficients because of the lower Type I error rate and higher statistical power (Preacher and Hayes, 2004). Table 3 displays the significant mediating effect of innovation on the relationship between the three types of supplier collaboration $(Z=2.95, p<0.001$ with 
strategic collaboration; $Z=3.36, p<0.001$ with operation collaboration; $Z=4.07, p<0.001$ with product development collaboration), confirming hypothesis 5. The effect ratio of each suggests a full mediation effect (Jose, 2008).

Table 3

Results of Sobel test of the mediating effect of innovation

\begin{tabular}{cccccccc}
\hline Mediator & $\mathrm{c}$ & $\mathrm{a}$ & $\sigma \mathrm{a}$ & $\mathrm{b}$ & $\sigma \mathrm{b}$ & $\mathrm{Z}$ & $\mathrm{Effect}$ ratio \\
\hline $\begin{array}{c}\text { Innovation } \\
\text { over strategic collaboration }\end{array}$ & 0.17 & 0.15 & 0.00 & 0.2 & 0.00 & $2.95^{* * * *}$ & 0.18 \\
$\begin{array}{c}\text { Innovation } \\
\text { over operational collaboration }\end{array}$ & 0.13 & 0.15 & 0.00 & 0.2 & 0.00 & $3.36^{* * * *}$ \\
$\begin{array}{c}\text { Innovation } \\
\text { over product development collaboration }\end{array}$ & 0.17 & 0.23 & 0.00 & 0.19 & 0.00 & $4.07^{* * *}$ \\
\hline
\end{tabular}

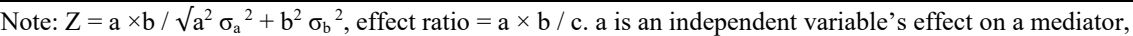

$\mathrm{b}$ is a mediator's effect on a dependent variable, and $\mathrm{c}$ is an independent variable's effect on a dependent variable.

$* * * \mathrm{p}<.001$ (two-tailed).

\section{Conclusion}

The study examined the effects of supplier collaboration on environmental performance and focused on the mediating effect of innovation capabilities. Previous studies have focused on the direct relationship between supplier collaboration and environmental performance, arguing that collaboration helps firms deal with complex technologies that need a high level of cooperation and complementarity assets; researchers have given less attention to the mechanism between supplier collaboration and environmental performance.

We found that three types of supplier collaboration (strategic, operational, and product development) are beneficial for environmental performance $(\mathrm{H} 1.1, \mathrm{H} 1.2$, and $\mathrm{H} 1.3)$. We also found that innovation capabilities are positively and significantly associated with environmental performance (H2). Furthermore, innovation capabilities mediated the relationship between the three types of supplier collaboration and environmental performance (H3).

Our results contribute to the current literature in two ways. First, we investigated multiple types of supplier collaboration and showed that each of the three types we chose has positive effects on environmental performance. Operational and product development collaboration with suppliers help firms solve practical problems in pursuing environmental performance, while strategic collaboration provides a foundation on which firms can efficiently and effectively work with suppliers through a long-term partnership.

In addition, we revealed a mechanism through which supplier collaboration provides a positive effect on environmental performance. More specifically, we demonstrated the mediating effect of innovation on the three types of supplier collaboration and environmental performance. Efforts to collaborate with suppliers for environmental performance also lead to increased innovation, enabling firms to manage more complex and diverse technologies. Finally, increased innovation capabilities positively influence environmental performance. These results describe how supplier collaboration increases environmental performance.

Our study provides practical implications for environmental performance. Firms deciding whether to pursue environmental initiatives may consider these efforts as burdensome because of failing to understand the link between environmental performance and profits. Our findings can help these firms understand why environmental initiatives contribute to stronger innovation capabilities as well as environmental performance, implying that these initiatives are complementary to other profit-generating activities. Second, supplier collaboration can be categorized into multiple dimensions, of which we considered strategic, operational, and product development. While all three dimensions are beneficial for environmental performance, the rationale differs; firms need to find balance among the three dimensions to optimize environmental performance.

One limitation of our study is that our sample of Korean manufacturing firms may lack generalizability since the relatively strong pressure and legal environment has encouraged environmental performance in Korean firms. Future studies should be conducted in other geographic areas to confirm the external validity of our study. Although we focus on supplier collaboration given the important role of supply chains, different targets of collaboration like customers, research organizations, and competitors are likely to reveal other relationships with environmental performance.

\section{Acknowledgements}

This work was supported by the Ministry of Education of the Republic of Korea and the National Research Foundation of Korea (NRF-2017S1A5A2A03069011). This work was supported by 2020 Hongik University Research Fund. 


\section{References}

Baron, R. M., \& Kenny, D. A. (1986). The moderator-mediator variable distinction in social psychological research: Conceptual, strategic, and statistical considerations. Journal of Personality and Social Psychology, 51(6), 1173.

Bonaccorsi, A., \& Lipparini, A. (1994). Strategic partnerships in new product development: an Italian case study. Journal of Product Innovation Management, 11(2), 134-145.

Campion, M. A., Medsker, G. J., \& Higgs, A. C. (1993). Relations between work group characteristics and effectiveness: Implications for designing effective work groups. Personnel Psychology, 46(4), 823-847.

Chen, Y.-S. (2008). The driver of green innovation and green image-green core competence. Journal of Business Ethics, $81(3), 531-543$.

Chiou, T.-Y., Chan, H. K., Lettice, F., \& Chung, S. H. (2011). The influence of greening the suppliers and green innovation on environmental performance and competitive advantage in Taiwan. Transportation Research Part E: Logistics and Transportation Review, 47(6), 822-836.

Clark, K. B., Fujimoto, T., \& Cook, A. (1991). Product development performance: Strategy, organization, and management in the world auto industry: Harvard Business School Press Boston, MA.

Cohen, W. M., \& Levinthal, D. A. (1990). Absorptive capacity: A new perspective on learning and innovation. Administrative Science Quarterly, 35(1), 128-152.

Cooper, R. G., \& De Brentani, U. (1991). New industrial financial services: what distinguishes the winners. Journal of Product Innovation Management, 8(2), 75-90.

Dangelico, R. M., \& Pujari, D. (2010). Mainstreaming green product innovation: Why and how companies integrate environmental sustainability. Journal of Business Ethics, 95(3), 471-486.

De Bakker, F. G., Fisscher, O. A., \& Brack, A. J. (2002). Organizing product-oriented environmental management from a firm's perspective. Journal of Cleaner Production, 10(5), 455-464.

De Marchi, V. (2012). Environmental innovation and R\&D cooperation: Empirical evidence from Spanish manufacturing firms. Research Policy, 41(3), 614-623.

Geffen, C. A. (1998). Innovative environmental technologies in automotive painting: The role of suppliers. doctoral thesis, Massachusetts Institute of Technology, Cambridge, MA.

Geffen, C. A., \& Rothenberg, S. (2000). Suppliers and environmental innovation: The automotive paint process. International Journal of Operations \& Production Management, 20(2), 166-186. doi:doi:10.1108/01443570010304242

Gimenez, C., \& Tachizawa, E. M. (2012). Extending sustainability to suppliers: a systematic literature review. Supply Chain Management: An International Journal, 17(5), 531-543.

Goldenberg, J., Lehmann, D. R., \& Mazursky, D. (1999). The primacy of the idea itself as a predictor of new product success: Marketing Science Institute.

Green, K., Morton, B., \& New, S. (1998). Green purchasing and supply policies: do they improve companies' environmental performance? Supply Chain Management: An International Journal, 3(2), 89-95.

Henriques, I., \& Sadorsky, P. (1999). The relationship between environmental commitment and managerial perceptions of stakeholder importance. Academy of Management Journal, 42(1), 87-99.

Hoegl, M., \& Gemuenden, H. G. (2001). Teamwork quality and the success of innovative projects: A theoretical concept and empirical evidence. Organization Science, 12(4), 435-449.

Jakobsen, S., \& Clausen, T. H. (2016). Innovating for a greener future: the direct and indirect effects of firms' environmental objectives on the innovation process. Journal of Cleaner Production, 128, 131-141.

Jose, P. (2008). Workshop on statistical mediation and moderation: Statistical mediation. In Proceedings of the SASP Conference, Wellington, New Zealand.

King, A. A., \& Lenox, M. J. (2001). Lean and green? An empirical examination of the relationship between lean production and environmental performance. Production and Operations Management, 10(3), 244-256.

Klassen, R. D., \& Whybark, D. C. (1999). The Impact of Environmental Technologies on Manufacturing Performance. Academy of Management Journal, 42(6), 599-615. doi:10.5465/256982

Loch, C. H., \& Terwiesch, C. (1998). Communication and uncertainty in concurrent engineering. Management Science, 44(8), 1032-1048.

Mondéjar-Jiménez, J., Segarra-Oña, M., Peiró-Signes, Á., Payá-Martínez, A. M., \& Sáez-Martínez, F. J. (2015). Segmentation of the Spanish automotive industry with respect to the environmental orientation of firms: Towards an ad-hoc vertical policy to promote eco-innovation. Journal of Cleaner Production, 86, 238-244.

O'Connor, G. C. (1998). Market learning and radical innovation: A cross case comparison of eight radical innovation projects. Journal of Product Innovation Management: An International Publications of the Product Development, 15(2), $151-166$.

Prahinski, C., \& Kocabasoglu, C. (2006). Empirical research opportunities in reverse supply chains. Omega, 34(6), 519532.

Preacher, K. J., \& Hayes, A. F. (2004). SPSS and SAS procedures for estimating indirect effects in simple mediation models. Behavior Research Methods, Instruments, \& Computers, 36(4), 717-731.

Primo, M. A., \& Amundson, S. D. (2002). An exploratory study of the effects of supplier relationships on new product development outcomes. Journal of Operations Management, 20(1), 33-52.

Ragatz, G. L., Handfield, R. B., \& Petersen, K. J. (2002). Benefits associated with supplier integration into new product development under conditions of technology uncertainty. Journal of Business Research, 55(5), 389-400. 
Rao, P., \& Holt, D. (2005). Do green supply chains lead to competitiveness and economic performance? International Journal of Operations \& Production Management, 25(9), 898-916.

Rogers, E. M., \& Williams, D. (1983). Diffusion of. Innovations (Glencoe, IL: The Free Press, 1962).

Rothenberg, S., \& Zyglidopoulos, S. C. (2007). Determinants of environmental innovation adoption in the printing industry: the importance of task environment. Business Strategy and the Environment, 16(1), 39-49.

Rothenberg, S. L. (1999). Is lean green?: the relationship between manufacturing processes and environmental performance within different regulatory contexts. Massachusetts Institute of Technology.

Sobel, M. E. (1986). Some new results on indirect effects and their standard errors in covariance structure models. Sociological Methodology, 16, 159-186.

Song, M., \& Thieme, J. (2009). The Role of Suppliers in Market Intelligence Gathering for Radical and Incremental Innovation*. Journal of Product Innovation Management, 26(1), 43-57. doi:10.1111/j.1540-5885.2009.00333.x

Srivastava, S. K. (2007). Green supply-chain management: A state-of-the-art literature review. International Journal of Management Reviews, 9(1), 53-80. doi:10.1111/j.1468-2370.2007.00202.x

Takeishi, A. (2001). Bridging inter-and intra-firm boundaries: management of supplier involvement in automobile product development. Strategic Management Journal, 22(5), 403-433.

Tannenbaum, S. I., Beard, R. L., \& Salas, E. (1992). Team building and its influence on team effectiveness: An examination of conceptual and empirical developments Advances in Psychology, 82, 117-153.

Teece, D. J. (1986). Profiting from technological innovation: Implications for integration, collaboration, licensing and public policy. Research Policy, 15(6), 285-305.

Vachon, S., \& Klassen, R. D. (2008). Environmental management and manufacturing performance: The role of collaboration in the supply chain. International Journal of Production Economics, 111(2), 299-315.

Wagner, M., \& Schaltegger, S. (2004). The effect of corporate environmental strategy choice and environmental performance on competitiveness and economic performance: an empirical study of EU manufacturing. European Management Journal, 22(5), 557-572.

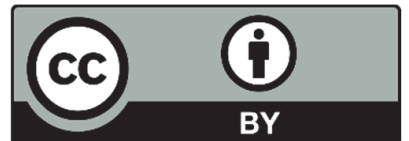

(C) 2020 by the authors; licensee Growing Science, Canada. This is an open access article distributed under the terms and conditions of the Creative Commons Attribution (CC-BY) license (http://creativecommons.org/licenses/by/4.0/). 